\title{
CORPORATE SOCIAL RESPONSIBILITY IN TIMES OF CRISIS: COVID-19
}

\author{
Marija Šain, PhD, Assistant Professor \\ Academy of Arts and Culture in Osijek, University J. J. Strossmayer in \\ Osijek \\ Kralja Petra Svačića 1/F, Croatia \\ marija.sain@aukos.hr
}

\begin{abstract}
Corporate social responsibility implies business with concern for ethics, human rights, community needs, and investment in environmental protection. It is especially evident in crisis situations when the expectations of the environment about the application of these principles of the company are higher. The Covid-19 pandemic, as a crisis situation in which companies found themselves, led to changes in business models that had an impact on their stakeholders as well. In this segment, corporate social responsibility can be a useful and effective way to mitigate the potential effects of a pandemic and make it easier to deal with the consequences of a crisis.

The aim of this paper is to provide a theoretical framework for the study of corporate social responsibility in crisis situations with special reference to the situation related to Covid-19. For this purpose, the research methodology includes a review of the literature on corporate social responsibility in this situation by classification into external (community, customer, and environment) and internal (employees) dimensions of the application of corporate social responsibility. The paper highlights the problems and challenges associated with corporate social responsibility in the Covid-19 pandemic and suggests further research opportunities in this area.
\end{abstract}

Keywords: corporate social responsibility, Covid-19, crisis, stakeholders, the external and internal dimension of CSR

\section{INTRODUCTION}

The European Commission defines corporate social responsibility (CSR) as „a process to integrate social, environmental, ethical, human rights and consumer concerns into their business operations and core strategy in close collaboration with their stakeholders, with the aim of maximizing the creation of shared value for their owners/shareholders and civil society at large and identifying, preventing 
and mitigating possible adverse impacts. " 1 Therefore, the concept of CSR is based on the belief that companies have some responsibilities to the company other than the profit for shareholders ${ }^{2}$ ie it is impossible to consider companies separate from the company in which they exist and social responsibility is necessary to all its stakeholders. ${ }^{3}$ This is particularly evident in crisis situations ${ }^{4}$ such as the current coronavirus pandemic ${ }^{5}$ that has affected all aspects of society and life; in economic, financial, health, environmental, and sociological terms. Companies were forced to adapt to the new situation, which meant adopting business strategies and activities to meet the needs of the company and its stakeholders. In this segment, the application of CSR can be a useful and effective way to deal with global problems; in developing corporate resilience and reducing the potential effects of crisis situations, ${ }^{6}$ but also how to turn a threat into an opportunity. ${ }^{7}$

The research questions that arise in the paper are to determine the importance of the application of CSR in crisis situations, ie does such a way of doing business help in overcoming crisis situations such as the Covid-19 pandemic? How do stakeholders perceive CSR activities in such situations, and what problems and challenges arise related to CSR at the time of Covid-19?

To answer these questions, the author analyzed the literature on CSR at the time of Covid-19 by classifying it into the external (consumers, community, and envi-

1 European Commission, Commission Staff Working document - Corporate Social Responsibility, Responsible Business Conduct, and Business and Human Rights: Overview of Progress, 2019, [https://ec.europa. eu/docsroom/documents/34482?locale=hr], Accessed 10 March 2021, p. 3.

2 Carroll, A. B.; Shabana, K. M., Business Case for Corporate Social Responsibility: A Review of Concepts, Research and Practice, International Journal of Management Reviews, Vol. 12, 2010, pp. 85 - 105.

3 Yelkikalan, N.; Köse, C., The effects of the financial crisis on corporate social responsibility, International Journal of Business and Social Science, Vol. 3, No. 3, 2012, pp. 292 - 300; Santos Jaen, J. M. et al., Impact on companies of their socially responsible actions in the face of the pandemic generated by Covid-19, Razon Historica-Revista Hispanoamericana de Historia de Las Ideas, No. 46, 2020, pp. 1 - 11.

4 García-Sánchez, I-M.; García-Sánchez, A., Corporate Social Responsibility during COVID-19 Pandemic, Journal of Open Innovation Technology, Market and Complexity, Vol. 6, No. 4, 2020, pp. 1 - 21; Mao, Y. et al., Effects of tourism CSR on employee psychological capital in the COVID-19 crisis: from the perspective of conservation of resources theory, Current Issues in Tourism, Vol. 23, 2020, pp. 1 -19.

5 The coronavirus outbreak, which started in China in December 2019, was spreading rapidly worldwide and was declared a pandemic by the World Health Organization (WHO) in March of 2020.

6 Huang, W.; Chen, S., Corporate Social Responsibility and Organizational Resilience to COVID-19 Crisis: An Empirical Study of Chinese Firms, Sustainability, Vol. 12, No. 21, 2020, pp. 1 - 19; Filimonau, V. et al., The COVID-19 pandemic and organizational commitment of senior hotel managers, International Journal of Hospitality Management, Vol. 91, 2020, pp. 1 - 13; Higgins-Desbiolles, F.; Monga, M., Transformative change through events business: a feminist ethic of care analysis of building the purpose economy, Journal of Sustainable Tourism, Vol. 28, 2020, pp. 1 - 19.

7 Fernández-Feijóo Souto, B., Crisis and Corporate Social Responsibility: Threat or Opportunity?, International Journal of Economic Sciences and Applied Research, Vol. 2, No. 1, 2009, pp. 36 - 50. 
ronment) and internal (employees) dimensions of CSR application. The paper is structured in such a way that in the first part the theoretical assumptions about the definition and concept of CSR and stakeholders and its application in crisis situations are presented. The research is based on the application of CSR in the Covid-19 situation according to the internal and external dimensions of CSR, and for this purpose, publicly available articles performed in the Web of Science and Scopus database are analyzed. The last chapter deals with the discussion and conclusion in which the author summarizes the ways companies respond to a crisis situation such as a coronavirus pandemic, but also the perception of its stakeholders to such activities and suggests further research opportunities in this area and limitations. Therefore, in addition to the systematization of recent literature, the scientific contribution of the work is in the recommendations for future research regarding the application of the concept of CSR in crisis situations.

\section{THEORETICAL BACKGROUND}

\subsection{CSR and stakeholder classification}

„Socially responsible business of the company implies attention with which we treat in an ethical and socially responsible way the stakeholders who are outside, but also within the organization. "8 Stakeholders are all those who have an impact, but also those who are affected by the business of a particular company. ${ }^{9}$ "The Stakeholder theory suggests that as a social organization, a company should consider the effect of its every action and its CSR involvement must benefit the people, community, and society on a large scale. ${ }^{10}$

Margolis and Walsh ${ }^{11}$ distinguish between the internal and external application of CSR, ie external stakeholders (local community, environment, and consumers) are beneficiaries of external CSR activities, and employees are beneficiaries of internal CSR activities. The specific CSR activities involved in this division relate to:

„CSR targeting the community can include support for humanitarian causes, charitable giving, community development investments, and collaboration with non-governmental organizations (Farooq, Payaud, et al., 2014). CSR supporting the environment can include environmentally conscious investments, pollution prevention, ecological initiatives

8 Hopkins, M., What is Corporate Social Responsibility all about, Journal of Public Affairs, Vol. 6, No. 3-4, 2006, p. 299.

$9 \quad$ Freeman, R. E., Strategic Management: A Stakeholder Approach, Pitman, Boston, 1984.

10 Costa, R.; Menichini, T., A multidimensional approach for CSR assessment: The importance of the stakeholder perception. Expert Systems with Applications, Vol. 40, No.1, 2013, p. 155.

11 Margolis, J. D.; Walsh, J. P., Misery loves companies: Rethinking social initiatives by business, Administrative Science Quarterly, Vol. 48, No. 2, 2003, pp. 268 - 305. 
focused on the natural environment, and practices focusing on sustainable growth for future generations. CSR targeting consumers relates to the responsibilities of a business toward those who receive its services or consume its products. CSR practices within this domain include product safety initiatives and customer care programs. Internal CSR refers to practices focused on stewardship toward the internal workforce (i.e., employees). This has included activities such as employee training, continuing education programs, safe working environments, diversity policies, daycare programs, and ethical labor practices“. ${ }^{12}$

Employees, consumers, and the community are considered vital stakeholders for the company because they are important for the business growth and long-term survival of the company and are also a central feature of all CSR Reports. ${ }^{13}$ Due to all these features, CSR activities in crisis situations are most often carried out according to this group of stakeholders, as evidenced by research in the circumstances of the Covid-19 pandemic, which was discussed in this paper. CSR activities towards the environment have become extremely relevant in recent years, and are often associated with the concept of sustainability and sustainable development, ie development that efficiently uses resources in a way that meets the needs of today, while not compromising the needs of future generations. ${ }^{14}$ Business sustainability must take into account the needs of the company as well as its stakeholders but at the same time, it must protect, sustain, and enhance the environmental, social, and economic resources that are crucial for the future. Sustainable business creates added value for the company, which reflects on the value of the company through its economic viability and financial utility. ${ }^{15}$ Other, external stakeholders of the company are suppliers, shareholders, the state, managers, NGOs, government, ecosystems, and business partners. ${ }^{16}$

Following the above, it is necessary to emphasize the importance of both the internal and external environment in which the company is located and use CSR activities that will have an impact on both dimensions and so „ensure the long term continuity of the company, by balancing profitability and stakeholder's

12 Farooq, O. et al., The Multiple Pathways through which Internal and External Corporate Social Responsibility Influence Organizational Identification and Multifoci Outcomes: The Moderating Role of Cultural and Social Orientations, The Academy of Management Journal, Vol. 60, No. 3, 2017, p. 957.

13 Mahmud, A. et al., Corporate Social Responsibility: Business Responses to Coronavirus (COVID-19) Pandemic, SAGE Open, Vol. 11, No. 1, 2021, pp. 1 - 17; Gürlek, M; Kılıç, İ., A true friend becomes apparent on a rainy day: corporate social responsibility practices of top hotels during the COVID-19 pandemic, Current Issues in Tourism, Vol. 24, No. 7, 2021, pp. $905-918$.

${ }_{14}$ Kolk, A., The social responsibility of international business: From ethics and the environment to CSR and sustainable development, Journal of World Business, Vol. 51, No. 1, 2016, pp. 23 - 34.

15 Pojasek, R. B., A framework for business sustainability, Environmental Quality Management, Vol. 17, No. 2, 2007, pp. $81-88$.

16 Mahmud et al., op. cit., note 13. 
harmony. ${ }^{17}$ In addition, there is a spillover effect between the internal and external dimensions of CSR implementation through „a) moral and social values such as social cohesion, social responsibility, unity, solidarity, equity of access to resources; and b) economic values like: novel response and readiness strategies, renovation of policies and standards, the capacity of change. " 18 The authors consider this spillover effect important in overcoming the crisis and improving functioning in the future, both for organizations and the community.

\subsection{The importance of CSR in times of crisis}

A crisis can be described in the general sense as a sequence of events (most probably unexpected) caused by internal or external factors, rapidly developing, undesired these can be threatening to the business and its environment. ${ }^{19}$ Crisis situations present a challenge for companies and „the recent extraordinary COVID-19 pandemic is not just the largest healthcare challenge of this century but it disrupts jobs (mass unemployment or reduced working hours on the labor market), the economy (some sectors are highly affected, e.g., tourism)..." ${ }^{20}$ In these circumstances, the concept of CSR comes to the fore, because then the social expectations of the company increase. ${ }^{21}$

Research shows that CSR in times of crisis has "an insurance-like function that mitigates the negative impact. "22 Companies that have used CSR even before crises will experience fewer losses, be more resilient, and take a shorter time to recover from attacks, unlike those companies that did not have or had weak CSR activities. ${ }^{23}$ Likewise, consumer sensitivity is greatest in times of crisis, and their perception of a company that carried out CSR activities during the crisis will positively affect their product consumption, punishing those who do not react in this way. ${ }^{24}$ However, if a company has overused corporate sponsorship based

17 García-Sánchez; García-Sánchez, op.cit., note 4, p. 18.

18 Ebrahim, A. H.; Buheji, M., A Pursuit for a 'Holistic Social Responsibility Strategic Framework' Addressing COVID-19 Pandemic Needs, American Journal of Economics, Vol. 10, No. 5, 2020, p. 301.

19 Yelkikalan; Köse, op. cit., note 3.

20 Kolnhofer Derecskei, A.; Nagy, V., Employee Volunteerism - Conceptual Study and the Current Situation, Sustainability, Vol. 12, No. 20, 2020, p. 23.

21 García-Sánchez.; García-Sánchez, op.cit., note 4.

22 Qiu, S. (C.) et al., Can corporate social responsibility protect firm value during the COVID-19 pandemic?, International Journal of Hospitality Management, Vol. 93, 2021, p. 4.

23 Huang; Chen, op. cit., note 6; Valls Martínez, M. d. C.; Martin Cervantes, P. A., Testing the Resilience of CSR Stocks during the COVID-19 Crisis: A Transcontinental Analysis, Mathematics, Vol. 9, 2021, pp. $1-24$.

24 Palma-Ruiz, J.M. et al. Socially Responsible Investing as a Competitive Strategy for Trading Companies in Times of Upheaval Amid COVID-19: Evidence from Spain, International Journal of Financial Studies, 
on CSR for marketing purposes, the initial positive customer perception of that company changes. ${ }^{25}$ Therefore, if used properly, CSR projects have a positive impact on consumer behavior ${ }^{26}$ Though significantly reduces the number and scope of CSR projects of large corporations in times of crisis ${ }^{27}$ which could also be related to the costs of implementing the CSR activities. ${ }^{28}$ Still, it needs to be looked at in the long run, because investing in CSR during a crisis has brought various benefits to the company such as increased reputation, profits, increased employee satisfaction, and opportunities to redefine trust between companies and society. ${ }^{29}$ Accordingly, CSR in crisis situations is extremely important in the successful response of organizations to such a situation, enabling its sustainability and better connection with stakeholders who know how to recognize and appreciate the efforts of these organizations.

\section{METHODOLOGY}

For the analysis of socially responsible business in the Covid-19 pandemic by classification Margolis and Walsh ${ }^{30}$ into external (community, customer, and environment) and internal (employees) dimensions of the application of corporate social responsibility and to find the potential for future research, a literature review by analyzing the extant literature was used. Systematic reviews help the research community understand better what has been empirically studied so far and what are the challenges for future research, based on the examined volume of previously published literature. ${ }^{31}$ The guidelines were used for a review of the literature with modifications adapted to the purpose of this research:

1. Define the research question(s) to be addressed;

Vol. 41, No. 8, 2020, pp. 1-13; Eltoum, A. M. et al., Corporate social responsibility practices of business firms in Dubai during the COVID-19 pandemic, Problems and Perspectives in Management, Vol. 19, No. 1, 2021, pp. 231- 243.

25 Fernández-Feijóo Souto, op. cit., note 7.

26 Mohr L. A., et. al., Do Consumers Expect Companies to be Socially Responsible? The Impact of Corporate Social Responsibility on Buying Behavior, The Journal of Consumer Affairs, Vol. 35, No. 1, 2001, pp. $45-72$.

27 Zengin Karaibrahimo, Y. Corporate social responsibility in times of financial crisis, African Journal of Business Management, Vol. 4, No. 4, 2010, pp. 382 - 389.

28 Fernández-Feijóo Souto, op.cit., note 7; Qiu, S. (C.) et al., Can corporate social responsibility protect firm value during the COVID-19 pandemic?, International Journal of Hospitality Management, Vol. 93, 2021, pp. $1-12$.

29 Santos Jaen et al., op. cit., note 3; Fernández-Feijóo Souto, op.cit., note 7; Qiu et al., op.cit., note 28.

30 Margolis; Walsh, op. cit., note 11.

31 Ginsberg, A.; Venkatraman, N., Contingency perspectives of organizational strategy: a critical review of the empirical research, Academy of Management Review, Vol. 10, No. 3, 1985, pp. 421 - 434. 
2. Search for (i) a set of bibliographic databases, and/or (ii) in a well-defined and justified journal sample using one or more predefined keywords;

3. Include the keywords in the search fields (title);

4. Analyze each article to identify the theoretical framework, a methodological approach, and interesting potential lines of research. ${ }^{32}$

The author chose the Web of Science and Scopus as bibliographic databases to search for relevant academic articles.

The literature search was based on the following criteria:

- Timespan: 2020 (1 March) to 2021 (until 1 March),

- All Citation Indexes,

- Document Types: Article,

- Key words: „CSR, Covid, employee“; „corporate responsibillity, Covid, employee“; „CSR, Covid, community“; „corporate responsibillity, Covid, community“; „CSR, Covid, consumer“; „corporate responsibillity, Covid, consumer"; „CSR, Covid, customer“; „corporate responsibillity, Covid, customer“; „CSR, Covid, environment“; „corporate responsibillity, Covid, environment".

- Open access.

Table 1 shows the research results from the Web of Science (WoS) and Scopus database according to the given criteria.

Table 1 Distribution of CSR stakeholder

\begin{tabular}{|l|c|c|c|}
\hline & Web of Science & Scopus & Total \\
\hline Employee & 14 & 10 & 24 \\
\hline Community & 8 & 9 & 17 \\
\hline Customer & 13 & 8 & 21 \\
\hline Environment & 8 & 6 & 14 \\
\hline Total & 43 & 33 & 76 \\
\hline
\end{tabular}

Source: Research results

As can be seen from the table, a total of 76 papers are from the WoS and Scopus databases that analyze the internal (24) and external (52) dimensions of CSR application. Not surprisingly, overlapping articles appeared in both Scopus and the Web of Science, so we had to merge both lists and remove duplicates (7 „em-

32 Vázquez-Carrasco, R.; López-Pérez, M. E., Small \& medium-sized enterprises and Corporate Social Responsibility: a systematic review of the literature, Quality \& Quantity, Vol. 47, No. 6, 2013, pp. 3205 -3218 . 
ployee“, 5 „,community“, 6 „customer“, 5 „environment“). The final list included 53 articles.

\section{INTERNAL AND EXTERNAL DIMENSION OF THE APPLICATION OF CSR}

Based on the results of the papers, the author identified overlaps in the articles, ie the same articles are in the results of different dimensions because several dimensions were also analyzed in the articles (24). Also, 1 paper could not be downloaded despite the open access criterion, 2 papers are not included in the topic (one research was conducted before the Covid situation and is not relevant to this topic and the second is not appropriate with topics) and are excluded from further analysis. The author removed the stated which is ultimately 26 papers for processing the internal and external dimensions of CSR application. According to the content and results of the papers, the author established the categories within the observed dimensions and processed them by the set. Interestingly, in almost a third of the papers (8), the research was conducted in tourism and hospitality firms.

\subsection{Internal dimension - Employee}

Based on the analysis of each article, the author divided the activities and the role of corporate social responsibility in the Covid-19 situation from the aspect of employees into two categories:

a) employee health and safety at work

b) job stability and work performance

a) Pandemic coronavirus highlighted the care of the health and safety of employees as the most important CSR activities towards this group of stakeholders. Mahmud et al. ${ }^{33}$ quote specific measures taken by companies to protect employees (on a sample of the top 25 companies in the USA), and these are nine mechanisms such as work at home / remotely $(60 \%)$, cleaning conventions and hygiene protocols $(56 \%)$, health elevated quarantine $(24 \%)$, and social distancing and travel restriction practices $(36 \%)$, as well as offer, paid leave and sick leave with health benefits $(48 \%)$, premium/bonus (16\%), employee volunteering benefits $(36 \%)$ and employee assistance programs (20\%). In the home office segment, Parker ${ }^{34}$ considers that such a management strategy reflects the choice of priorities between health

\footnotetext{
33 Mahmud et al., op. cit., note 13.

34 Parker, L. D., The Covid-19 office in transition: cost, efficiency, and the social responsibility business case, Accounting, Auditing and Accountability Journal, Vol. 33, No. 8, 2020, pp. 1943 - 1967.
} 
and safety at work over the company's financial returns, while Jakulevičienè and Gailiūtė-Janušonè ${ }^{35}$ argue that those companies that have previously provided opportunities for a better work-life balance by allowing their employees the opportunity to work remotely could adapt much more easily and quickly to the changing working conditions created by the COVID-19 pandemic and the resulting quarantine. Gürlek and Kılıç36 on a sample of 100 world hotels identified five categories of CSR for employees, namely: health and safety, employee assistance program, career planning, salary, and rewards, the most important of which is health and safety, which includes training of its employees on how to protect themselves. COVID-19 and the supply of protective equipment for employees and guests as well as intensive cleaning of surfaces (door handles, elevator, etc.), to make both employees and guests feel safe. Gökmen Kavak et al. ${ }^{37}$ in theirs paper emphasizes the importance of applying standards of risk management, health and safety of employees where such a course of action is the only correct and effective because by taking measures, the spread of disease can be minimized.

b) The coronavirus pandemic has created increased insecurity among employees, especially in tourism, which is the most affected branch in the pandemic, and most of the analyzed research was conducted in this industry. ${ }^{38}$ Filimonau et al. ${ }^{39}$ based on a sample of 244 senior managers in hotels in Spain, they found that hotel investment in CSR proved useful not only from the point of view of improved organizational resilience but also from the perspective of improved (perceived) job security and organizational commitment of senior management. Based on the results of a survey of 430 employees in tourism in China, Mao et al. ${ }^{40}$ have proven that CSR has had a positive impact on increasing the psychological capital of employees which includes: self-efficacy, hope, resilience, and optimism of employees through their satisfaction with corporate COVID-19 responses. In a sample consisting of 374 Vietnamese full-time employees in hotels, Vo-Than et

35 Jakulevičienė, L.; Gailiūtė-Janušonè, D., The scope of legal expectations from business in human rights: carrot or stick?, Entrepreneurship and Sustainability Issues, Vol. 8, No. 2, 2020, pp. 932 - 946.

36 Gürlek; Kılıç, op. cit., note 13.

37 Gökmen Kavak, D. et al., The importance of quality and accreditation in health care services in the process of struggle against Covid-19, Turkish Journal of Medical Sciences, Vol. 50, No. 8, 2020, pp. 1760 1770 .

38 Gürlek; Kılıç, op. cit., note 13.; Vo-Thanh, T et al., How does hotel employees'satisfaction with the organization's COVID-19 responses affect job insecurity and job performance?, Journal of Sustainable Tourism, Vol. 29, No. 6, 2020, pp. 907 - 925; Filimonau et al., op.cit., note 6; Mao et al., op. cit., note 4; Zhang, J.; Xie, C, The effect of corporate social responsibility on hotel employee safety behavior during COVID-19: The moderation of belief restoration and negative emotions, Journal of Hospitality and Tourism Management, Vol. 46, 2020, pp. 233- 243.

39 Filimonau, et al., op. cit., note 6.

40 Mao et al., op. cit., note 4, 
$a l^{41}$ concluded that employee satisfaction with COVID-19's responses positively affected their work performance and moderately positive links between perceived health risk associated with Covid and job security. Zhang and $\mathrm{Xie}^{42}$ are investigating the effect of CSR on employee safety behavior to 1594 respondents in 23 hotels in China where they conclusion that CSR practices of hotels are predicted employee positive work behavior, such as job engagement. Also, results indicated that employee perceptions of hotel CSR initiatives encouraged them to implement role safety behavior, such as complying with safety systems, as well as extrarole safety and citizenship behavior. Rivo-López et al ${ }^{43}$ investigate the activities of CSR family businesses in the Covid-19 pandemic and shows how such businesses have been supporting their employees by avoiding layoffs as well as paying full pay which means they are company has decided to think more about the long-term and its employees than its financial results. Jakulevičienè and Gailiūtė-Janušonè $\dot{e}^{44}$ and Santos Jaen $e t a l^{45}$ through their work, find that commitment to work grows as companies address the needs of employees, and even though their involvement in employee volunteering programs as part of CSR companies. Kolnhofer Derecskei; $\mathrm{Nagy}^{46}$ provide a preliminary study on how employee volunteering could work in the circumstances of the Covid-19 pandemic and states that such a situation could encourage employees to engage more in society (given that some will have more free time) while on the other hand, the effects of the pandemic may affect the reduced scope of employee volunteering (due to the increased risk of illness, lack of time because, for example, they have small children, etc.).

\subsection{External dimension - Community}

Based on the analysis of each article, the author divided the activities and role of corporate social responsibility in the Covid-19 situation from a community perspective into two categories:

a) helping the community cope with the crisis caused by the Covid-19 pandemic

b) the financial benefit of community CSR activities during a pandemic

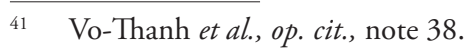

42 Zhang; Xie, op. cit., note 38.

43 Rivo-López, E. et al., Corporate Social Responsibility and Family Business in the Time of COVID-19: Changing Strategy?, Sustainability, Vol. 13, No. 4, 2021, pp. 1 - 13.

44 Jakulevičienė; Gailiūtè-Janušonè, op. cit., note 35.

45 Santos Jaen et al., op. cit., note 3.

46 Kolnhofer Derecskei, A.; Nagy, V., Employee Volunteerism —Conceptual Study and the Current Situation, Sustainability, Vol. 12, No. 20, 2020, pp. $1-35$.
} 
a) Gürlek; Kılıç ${ }^{47}$ divided CSR for community-oriented activities into three categories, namely CSR for health workers, the well-being of the local population, and health organizations. In particular, the hotels offered free accommodation for health professionals, donated protective equipment to the local population, and offered their facilities for health professionals. Mahmud et al. ${ }^{48}$ also cite concrete actions taken by the top 25 companies in the US where $80 \%$ of the company's samples reported their relief efforts were pointing to their global community to effectively manage the challenges associated with the COVID-19 pandemic. Grants include direct efforts to provide cash and in-kind assistance, as well as fundraising and donations to nonprofits. About $68 \%$ of the sampled companies are directly involved in aid activities with cash donations and $80 \%$ of companies with natural support. Nearly $40 \%$ of the companies in the sample use the funds of their foundations to support society during this pandemic. About $36 \%$ of the company's samples have contributed to international, national and regional non-profit organizations, such as the International Red Cross, WHO, etc. to support vulnerable people around the world and national communities. Also, some sampled companies have launched various programs to keep the world a better place for children, their parents and the community. Higgins-Desbiolles and Monga ${ }^{49}$ analyse of a case study of social entrepreneurship in Australia shows that it is imperative for businesses during, but also after the Covid-19 pandemic, to help build community, build care relationships and contribute to a more sustainable and fair future. Saiz-Álvarez et al..$^{50}$ analyse B Corps companies who are based on the conviction that it is possible to combine the concepts of social development and economic growth and given its purpose of existence, such companies go beyond the notion of CSR. These socioeconomic-related firms which base their purpose on helping the community, for this authors, can be one of the main pillars of the COVID-19 post-crisis. Eltoum et al. ${ }^{51}$ examined the level of expectations and assessment of the business of companies in Dubai when performing CSR during the crisis with a survey questionnaire on the citizens of Dubai (145 respondents). The largest number of respondents (44\%) believe that Dubai companies should prioritize the community in the Covid-19 crisis and then focus on their employees. In contrast to the results of the survey, the in-depth interview method determined that it was the pandemic time is the time for employees, then the community and no other

\footnotetext{
47 Gürlek; Kılıç, op. cit., note 13.

48 Mahmud et al., op. cit., note 13.

49 Higgins-Desbiolles, F.; Monga, M., Transformative change through events business: a feminist ethic of care analysis of building the purpose economy, Journal of Sustainable Tourism, Vol. 28, 2020, pp. 1 - 19.

50 Saiz-Álvarez, J. M. et al., B Corps: A Socioeconomic Approach for the COVID-19 Post-crisis, Frontiers in Psychology, Vol. 11, 2020, pp. $1-8$.

51 Eltoum et al., op. cit., note 24.
} 
rights are important at this time, neither investors nor shareholders, because these can wait. Job stability, health and safety for these employees should be a priority for the firm. Talbot and Ordonez-Ponce ${ }^{52}$ in the article showed how Canada's banks are supporting their clients and communities, during the current health crisis. Authors have conducted a content analysis of Canada's ten largest banks' web pages and results showed that only three of the banks analyzed to have a proactive and strong commitment to their clients and communities. For example, banks are helping the community through many CSR activities: psychological support for caregivers, and donations to non-profit organizations, donated masks and surgical masks, etc. Rivo-López et al..$^{53}$ explore how business families can contribute during emergencies through philanthropy or company CSR activities. The results show that philanthropic activities for (local) community no longer focus solely on traditional economic or material donations but also include knowledge and organizational capacity, which many companies have made available to various governments to help manage and end the pandemic. For example, it includes providing logistical support to the government to purchase and supply essential sanitary equipment and restructuring production plants, and directing lines to the healthcare field by manufacturing protective equipment, ventilators, and disinfectant gel. Also, the authors emphasize the important role of institutions and the state in encouraging CSR in times of crisis through various (tax) measures.

b) Jakulevičienè and Gailiūtè-Janušone ${ }^{54}$ in their research confirm that involvement and engagement with the community is not only a matter of risk mitigation but can also be financially beneficial. Qiu et al. ${ }^{55}$ agree, revealing in their study that participating in CSR activities can increase stock returns and the attention of hospitality stakeholders during a pandemic, stressing that community CSR has a stronger and more immediate impact on stock returns than CSR for customers and employees. The aim of Parker's paper ${ }^{56}$ is to assess how office efficiency and cost control programs concerning government and community health and safety expectations in the Covid-19 situation intersect with corporate social responsibility. Research shows that Covid-19 caused a shift in teleworking and organizations continued (given that the pandemic is still ongoing) „with office cost reduction strategies under the guise of innovative office design. "57

\footnotetext{
52 Talbot, D.; Ordonez-Ponce, E., Canadian banks' responses to COVID-19: a strategic positioning analysis, Journal of Sustainable Finance \& Investment, Vol. 10, 2020, pp. 1 - 8.

53 Rivo-López et al., op. cit., note 43.

54 Jakulevičienè; Gailiūtè-Janušonè, op. cit., note 35.

55 Qiuet et al., op. cit., note 28.

56 Parker, op. cit., note 34.

57 Ibid, p. 1943.
} 


\subsection{External dimension - Customer}

Based on the analysis of each article, the author divided the activities and the role of corporate social responsibility in the Covid-19 situation from the customer's perspective into two categories:

a) CSR towards customer

b) consumer perception of CSR activities of the company

a) Mahmud et al. ${ }^{58}$ note that about $92 \%$ of the companies in the analyzed sample continued to work to provide their products to customers such as the supply of food, medicines, protective supplies, medical equipment, information, and other services. As for tourism, in a survey of 100 world hotels, ${ }^{59}$ CSR activities include: health and safety of guests, additional disinfection of contact services (door handle, elevator, etc.), provision of free disinfectants, flexible booking rules and prices - waiver of the right to charge for changes and cancellation of purchased tickets. Winet and Winet ${ }^{60}$ analyse another dimension of consumer concern, and that is that the pandemic has spurred an unprecedented e-mail inbox from companies that claim we are "all in it together" creating, according to the authors, a false sense of empathy. Consumer relationship with the brand at a time when online shopping is at its peak and such e-mail brings the company's product to the forefront. Smith and Casper ${ }^{61}$ investigated CSR in major U.S. sports organizations at the time of the Covid-19 pandemic. The results of the research indicate their positive impact on society, ie fans where crisis communication took place through three topics: educate, (educate fans about proper social distancing in stadiums, arenas, and other social gatherings for their safety and health), assist (leagues will have to shift programs and support to long-term issues such as the economic impact of COVID-19) and inspire (shifting from shelter-in-place focused communication to long-term positivity needed by fans). Talbot and Ordonez-Ponce ${ }^{62}$ show how Canada's banks are supporting their personal and business clients during the current health crisis. Most banks are not proactive about meeting the pandemic market's unique challenges. Three from ten analyzes banks have the same CSR activities. For example, for business clients, the banks from this cluster also stand out for offering increased operating credit lines and reduced interest rates for

\footnotetext{
$58 \quad$ Mahmud et al., op. cit., note 13.

59 Gürlek; Kılıç, op. cit., note 13.

60 Winet, K; Winet, R. L., We're Here for You: The Unsolicited Covid-19 Email, Journal of Business and Technical Communication, Vol. 35, No. 1, 2021, pp. $134-139$.

61 Smith, D. K.; Casper, J., Making an Impact: An Initial Review of U.S. Sport League Corporate Social Responsibility Responses During COVID-19, International Journal of Sport Communication, Vol. 13, No. 3, 2020, pp. $335-343$.

62 Talbot; Ordonez-Ponce, op. cit., note 53.
} 
credit. They have also adopted some very innovative initiatives, such as suspended student loan payments for six months without interest, and some banks offer a psychological and legal assistance line for their clients.

b) Yang et al. ${ }^{63}$ surveyed 473 respondents on how the dimensions of retailer service quality in the Covid-19 situation affect legitimacy, leading to a certain intention and behavior of consumers. The results establish that hygienic practice, reliability, safety, and empathy are determinants of pragmatic and social legitimacy, which encourages the consumer's intention to visit the retailer again. Liu et al. ${ }^{64}$ based on an empirical analysis of 946 SMEs, they find that CSR SMEs can enhance consumer brand attitudes and that consumers positively perceive corporate selfsacrifice during the Covid-19 pandemic, resulting in a spillover that improves consumer attitudes about that business. Chua et al. ${ }^{65}$ explore the perception of future behavior of American tourists towards European and Asian destinations under the influence of international travel risk and insecurity caused by the COVID-19 pandemic. The results of research on a sample of 367 respondents show that in the case of a pandemic Covid-19; CSR and observed efforts were crucial to generate attachment to destination and approach intentional behaviors, as well as that health preventative behavior and destination attachment, were important direct predictors of approach to intentional behavior. Also, it was found that monetary promotions were not sufficient to create destination attachment and bring the intentions of conduct closer to the international destination. Smith and Casper ${ }^{66}$ researched CSR in major U.S. sports organizations at the time of the Covid-19 pandemic and investigated fan reaction to CSR programs implemented by those organizations. The analysis shows different effects in how fans feel in response to league CSR social media communications. It is positive in gratitude toward continued support ligues of fighting the pandemic and other causes and negative that they felt the ligues was not doing enough. Huang and $\mathrm{Liu}^{67}$ provide empirical evidence to underscore the importance of CSR marketing in the time of COVID-19

63 Yang, K. et al., Effects of retailers'service quality and legitimacy on behavioral intention: the role of emotions during COVID-19, The Service Industries Journal, Vol. 41, No. 1-2, 2021. pp. 84 - 106.

64 Liu, F. et al., The influence of the corporate social responsibility disclosures on consumer brand attitudes under the impact of COVID-19, Frontiers of Business Research in China, Vol. 14, No. 28, 2020, pp. $1-22$.

65 Chua, B.-L. et al., Tourists' outbound travel behavior in the aftermath of the COVID-19: role of corporate social responsibility, response effort, and health prevention, Journal of Sustainable Tourism, Vol. 28, 2020, pp. $1-28$.

66 Smith; Casper, op. cit., note 62.

67 Huang, H.; Liu, S. Q., Donate to help combat COVID-19!" How typeface affects the effectiveness of CSR marketing? International Journal of Contemporary Hospitality Management, Vol. 32, No. 10, 2020, pp. $3315-3333$. 
for hospitality organizations striving to capture customer loyalty. The article demonstrates that a well-made donation appeal can effectively encourage consumers' participation in COVID-19 fundraising campaigns and boost their brand loyalty. Results suggest that donation appeals featuring warmth-focused messages combined with hand-written type and competence-focused messages combined with machine-written typeface lead to higher donation intention and brand loyalty.

\subsection{External dimension - Environment}

Based on the analysis of each article, the author divided the activities and role of corporate social responsibility in the Covid-19 situation from the aspect of the environment into two categories:

a) CSR towards the environment

b) individual social responsibility

a) The environmental responsibility of companies as part of the CSR where the Covid-19 situation further highlighted the need for interdependence between social, environmental, and economic well-being by emphasizing the importance of socially and environmentally responsible business sector behavior. ${ }^{68}$ Ikram et al. ${ }^{69}$ state that the COVID-19 pandemic is a new challenge for the sustainability of enterprises, which is now marginalized mainly due to supply chains and their manufacturers, but is also an opportunity for organizations to review their sustainable business practices in changing their production strategy, supply chain and sustainability. Businesses and organizations are also responsible for the environment (sustainability) and for the community in which they operate, and this should be embedded in their corporate values, which represent general beliefs about what is or is not appropriate behavior. ${ }^{70}$ Related to this, Yang et al. ${ }^{71}$ view organizations as part of a complex ecological system consisting of socio-cultural norms that must be respected for sustainable development. The coronavirus pandemic requires the strengthening of the partnership between government, the economy, and civil society and their socially responsible behavior, the introduction and respect of new forms of interaction between business and society on the principles of systematicity and long-term. ${ }^{72}$

68 Huang; Chen, op. cit., note 6.

69 Ikram, M. et. al., The Social Dimensions of Corporate Sustainability: An Integrative Framework Including COVID-19 Insights, Sustainability, Vol. 12, No. 20, 2020, pp. 1 - 29.

70 Kolnhofer Derecskei; Nagy, op. cit., note 46.

71 Yang et al., op. cit., note 64, p. 86.

72 Galetska, T. et al., Social Responsibility of Economic Enterprises as a Social Good: Practice of the EU and Ukraine, Baltic Journal of Economic Studies, Vol. 6, No. 3, 2020, pp. 24 - 35 
b) Given the effects of the pandemic itself related to the system of production and consumption, Nova-Reyes et al. ${ }^{73}$ analyse whether consumers exhibit socially responsible behavior during the Covid-19 pandemic. The authors find that consumers exhibit irresponsible behaviors (such as excessive demand for medical (e.g., masks and gloves) and other necessary products (toilet paper and disinfectants) that are temporary. According to the authors, a structural change to a more rational and sustainable consumption model is needed. Related to this, Vanapalli et al..$^{74}$ point out that the pandemic has affected our behavior patterns such as the demand for personal protective equipment, as well as the increased demand for plastic-packed food and groceries and the use of disposable utensils, which increases waste and the need to manage it. The authors conclude the need to switch to environmentally friendly materials with the application of individual responsibility, corporate action, and government policy to prevent the transition from one disaster to another. In paper, Terres et al. ${ }^{75}$ emphasize the importance of applying prosocial behavior and consumption that reduces the negative effects of negative emotions caused by social alienation and promotes well-being during the COVID-19 crisis. Such behavior, according to the authors, would be beneficial not only to consumers, whose hopes and well-being would increase as a result, but also to companies in terms of increased sales and improved brand engagement, but also general awareness of sustainability needs. He and Harris ${ }^{76}$ emphasize the ethical dimension of consumer decision that became prominent during the pandemic, and which is likely to redirect consumers to prosocial consumption.

\section{DISCUSSION AND CONCLUSION}

This paper aimed to theoretically address the application of CSR during the Covid-19 pandemic, concerning the internal (employees) and external (community, consumers, and environment) dimensions of CSR application. The research describes the important role of CSR during the crisis and examines the impact of the pandemic on the CSR practice of companies, as well as the perception of stakeholders about these activities. By reviewing the analyzed literature according to the internal and external dimensions of CSR application, the author determined

73 Nova-Reyes, A. et al., The Tipping Point in the Status of Socially Responsible Consumer Behavior Research? A Bibliometric Analysis, Sustainability, Vol. 12, No. 8, 2020, pp. 1 - 23.

74 Vanapalli, K., R. et.al., Challenges and strategies for effective plastic waste management during and post COVID-19 pandemic, Science of The Total Environment, Vol. 750, 2021, pp. 1 - 10

75 Terres, M. da S. et al., The COVID-19 Pandemic: paths for future research in marketing involving the regulatory role of prosocial consumption, Brazilian Journal of Marketing, Vol. 19, No. 3, 2020, pp. 611 -641 .

76 He, H.; Harris, L., The impact of Covid-19 pandemic on corporate social responsibility and marketing philosophy, Journal of Business Research, Vol. 116, 2020, pp. 176 - 182. 
the categories within the observed dimensions. From the aspect of employees, two categories have been identified: employee health and safety, and job stability, and work performance. Within CSR, the health and safety of employees were strongly emphasized in the 1970s, while in recent decades research has focused more on employee morale and productivity, probably for the financial benefit of organizations. ${ }^{77}$ The time of the Covid-19 pandemic re-emphasized the concern for the health and safety of employees, and the analyzed companies took the necessary measures to ensure this in their workplaces. Likewise, the pandemic has created increased insecurity among employees in terms of their employment (especially in tourism). It is noticed that the use of CSR activities of the company in which they work, affects the positive perception of employees about job security, which consequently has a positive effect on their work performance, but also on increasing their psychological capital. Companies that take care of their employees have tremendous benefits, even in crisis situations because human capital is the predictor that had the greatest impact on an organization's resilience at the time of Covid-19, followed by economic capital. ${ }^{78}$ The challenges faced by companies in the Covid-19 situation are to comply with all regulations imposed by governments, experts, but also society. In addition to (costs) of supplying safety equipment (masks, disinfectants...) for their stakeholders, companies implement measures for the health and safety of employees, most often provided the equipment needed to work from home. This way of working has opened up some new issues that need to be regulated at higher levels (for example, the cost of working from home, and on the other hand, the costs of the company have been reduced). From a community perspective, two categories have been identified: helping the community cope with the crisis caused by the Covid-19 pandemic, and the financial benefit of CSR activities in the community during the pandemic. The results of the research show that the care for the community included mostly the care for those who were most exposed to the impact of the pandemic or the virus, namely health professionals. Through donations of necessary equipment and the provision of their premises and financial contributions, companies have helped the community cope with the effects of the pandemic. Besides, some companies provided their logistical support to the state, knowledge, and capacity to work together to combat the pandemic. Although these activities require new costs for the company, research shows that there is a long-term financial return because the community appreciates the efforts of the company. From the consumer aspect, two categories have been identified: CSR towards consumers, and consumer perception of CSR companies. As with employees, companies have taken great care of the health and

Parker, op. cit., note 34 .

78 Filimonau et al., op. cit., note 6. 
safety of their customers, but have also provided some flexibility in their business for the benefit of consumers (especially in tourism - for example, waiving the right to charge changes and cancel tickets; but also in the banking sector - deferred payments due to financial difficulties their clients). It is these activities that affect the positive perception of consumers, which improves consumer attitudes about the company and encourages its loyalty, which helps companies increase their market, reputation, and image. From the aspect of the environment, two categories have been identified: CSR towards the environment and individual social responsibility. Due to the detrimental impact that COVID-19 has had globally, significant changes in consumer behavior have occurred. Their individual social responsibility in the segment of product consumption is questionable, and the importance of the application of prosocial behavior and consumption is emphasized. On the other hand, the changes brought about by the pandemic affect the environment and sustainable development, and the synergy of individuals, companies and the state in the more efficient management of the area is needed.

Accordingly, CSR in crisis situations should be tailored to the needs of both external and internal stakeholders, ${ }^{79}$ (although it is not possible to make all stakeholders happy), ${ }^{80}$ but also not to forget the needs of the company. The paper finds that CSR has an important role in dealing with and overcoming the crisis, enables the development of resilience and more successful response to the situation, contributes to better connections with stakeholders who return positively perceive the efforts and investments of the company. Investing in CSR, although a cost in the short term, brings exceptional benefits to both the company and its stakeholders in the long run. It is therefore useful for companies to apply CSR not only in crisis situations but also regular basis as it will be easier to deal with a crisis when it occurs. Crisis situations, among other things, offer an opportunity for companies to be actively involved in some of the CSR activities and thus gain a new dimension of their business and development.

In addition to a systematic review of the literature, the paper presents the problems and challenges associated with CSR in the Covid-19 situation about the internal and external dimensions of its application, which provides an opportunity for future research. Despite the contribution of this study to the literature, several limitations are worth mentioning. Since the Covid-19 pandemic officially began in March 2020, and this study covered one year from the start of the pandemic, which included a specific sample from the Web of Science and Scopus databases, it is necessary to conduct tests after a certain time lag because is certainly increased

\footnotetext{
79 Fernández-Feijóo Souto, op. cit., note 7.

80 Gürlek; Kılıç, op. cit., note 13.
} 
the number of published papers that could be analyzed and thus get a deeper analysis and conclusions in this area. Also, the research was based on three stakeholders, in future studies, it is possible to focus on only one of the stakeholders or include those who were not included in this research as well as to conduct an analysis of papers from other databases with multiple keywords included, i.e. all the synonyms. These limitations imply recommendations for future research of this type.

\section{REFERENCES}

\section{BOOKS AND ARTICLES}

1. Carroll, A. B.; Shabana, K. M., Business Case for Corporate Social Responsibility: A Review of Concepts, Research and Practice, International Journal of Management Reviews, Vol. 12, 2010, pp. $85-105$

2. Chua, B.-L. et al., Tourists' outbound travel behavior in the aftermath of the COVID-19: role of corporate social responsibility, response effort, and health prevention, Journal of Sustainable Tourism, Vol. 28, 2020, pp. 1 - 28

3. Costa, R.; Menichini, T., A multidimensional approach for CSR assessment: The importance of the stakeholder perception. Expert Systems with Applications, Vol. 40, No.1, 2013, pp. 150 161

4. Ebrahim, A. H.; Buheji, M., A Pursuit for a 'Holistic Social Responsibility Strategic Framework' Addressing COVID-19 Pandemic Needs, American Journal of Economics, Vol. 10, No. 5, 2020, pp. $293-304$

5. Eltoum, A. M. et al., Corporate social responsibility practices of business firms in Dubai during the COVID-19 pandemic, Problems and Perspectives in Management, Vol. 19, No. 1, 2021, pp. $231-243$

6. Farooq, O. et al., The Multiple Pathways through which Internal and External Corporate Social Responsibility Influence Organizational Identification and Multifoci Outcomes: The Moderating Role of Cultural and Social Orientations, The Academy of Management Journal, Vol. 60, No. 3, 2017, pp. $954-985$

7. Fernández-Feijóo Souto, B., Crisis and Corporate Social Responsibility: Threat or Opportunity, International Journal of Economic Sciences and Applied Research, Vol. 2, No. 1, 2009, pp. $36-50$

8. Filimonau, V. et al., The COVID-19 pandemic and organizational commitment of senior hotel managers, International Journal of Hospitality Management, Vol. 91, 2020, pp. 1 - 13

9. Freeman, R. E., Strategic Management: A Stakeholder Approach, Pitman, Boston, 1984

10. Galetska, T. et al., Social Responsibility of Economic Enterprises as a Social Good: Practice of the EU and Ukraine, Baltic Journal of Economic Studies, Vol. 6, No. 3, 2020, pp. 24 - 35

11. García-Sánchez, I-M.; García-Sánchez, A., Corporate Social Responsibility during COVID-19 Pandemic, Journal of Open Innovation Technology, Market and Complexity, Vol. 6, No. 4, 2020, pp. $1-21$ 
12. Ginsberg, A.; Venkatraman, N., Contingency perspectives of organizational strategy: a critical review of the empirical research. Academy of Management Review, Vol. 10, No. 3, 1985, pp. $421-434$

13. Gökmen Kavak, D. et al., The importance of quality and accreditation in health care services in the process of struggle against Covid-19, Turkish Journal of Medical Sciences, Vol. 50, No. 8, 2020, pp. $1760-1770$

14. Gürlek, M; Kılıç, İ., A true friend becomes apparent on a rainy day: corporate social responsibility practices of top hotels during the COVID-19 pandemic, Current Issues in Tourism, Vol. 24, No. 7, 2021, pp. $905-918$

15. He, H.; Harris, L., The impact of Covid-19 pandemic on corporate social responsibility and marketing philosophy, Journal of Business Research, Vol. 116, 2020, pp. 176 - 182

16. Higgins-Desbiolles, F.; Monga, M., Transformative change through events business: a feminist ethic of care analysis of building the purpose economy, Journal of Sustainable Tourism, Vol. 28, 2020, pp. 1 - 19

17. Hopkins, M., What is Corporate Social Responsibility all about, Journal of Public Affairs, Vol. 6, No. 3-4, 2006, pp. 298 - 306

18. Huang, H.; Liu, S. Q., Donate to help combat COVID-19!" How typeface affects the effectiveness of CSR marketing? International Journal of Contemporary Hospitality Management, Vol. 32, No. 10, 2020, pp. 3315 - 3333

19. Huang, W.; Chen, S., Corporate Social Responsibility and Organizational Resilience to COVID-19 Crisis: An Empirical Study of Chinese Firms, Sustainability, Vol. 12, No. 21, 2020, pp. 1 - 19

20. Ikram, M. et. al., The Social Dimensions of Corporate Sustainability: An Integrative Framework Including COVID-19 Insights, Sustainability, Vol. 12, No. 20, 2020, pp. 1 - 29

21. Jakulevičienè, L.; Gailiūtė-Janušonè, D., The scope of legal expectations from business in human rights: carrot or stick?, Entrepreneurship and Sustainability Issues, Vol. 8, No. 2, 2020, pp. $932-946$

22. Kolk, A., The social responsibility of international business: From ethics and the environment to CSR and sustainable development, Journal of World Business, Vol. 51, No. 1, 2016, pp. $23-34$

23. Kolnhofer Derecskei, A.; Nagy, V., Employee Volunteerism - Conceptual Study and the Current Situation, Sustainability, Vol. 12, No. 20, 2020, pp. 1 - 35

24. Liu, F. et al., The influence of the corporate social responsibility disclosures on consumer brand attitudes under the impact of COVID-19, Frontiers of Business Research in China, Vol. 14, No. 28, 2020, pp. 1 - 22

25. Mahmud, A. et al., Corporate Social Responsibility: Business Responses to Coronavirus (COVID-19) Pandemic, SAGE Open, Vol. 11, No. 1, 2021, pp. 1 - 17

26. Mao, Y. et al., Effects of tourism CSR on employee psychological capital in the COVID-19 crisis: from the perspective of conservation of resources theory, Current Issues in Tourism, Vol. 23, 2020, pp. $1-19$

27. Margolis, J. D.; Walsh, J. P., Misery loves companies: Rethinking social initiatives by business, Administrative Science Quarterly, Vol. 48, No. 2, 2003, pp. 268 - 305 
28. Mohr L. A. et al., Do Consumers Expect Companies to be Socially Responsible? The Impact of Corporate Social Responsibility on Buying Behavior, The Journal of Consumer Affairs, Vol. 35, No. 1, 2001, pp. $45-72$

29. Nova-Reyes, A. et al., The Tipping Point in the Status of Socially Responsible Consumer Behavior Research? A Bibliometric Analysis, Sustainability, Vol. 12, No. 8, 2020, pp. 1 - 23

30. Palma-Ruiz, J.M. et al., Socially Responsible Investing as a Competitive Strategy for Trading Companies in Times of Upheaval Amid COVID-19: Evidence from Spain, International Journal of Financial Studies, Vol. 41, No. 8, 2020, pp. 1 - 13

31. Parker, L. D., The Covid-19 office in transition: cost, efficiency and the social responsibility business case, Accounting, Auditing and Accountability Journal, Vol. 33, No. 8, 2020, pp. $1943-1967$

32. Pojasek, R. B., A framework for business sustainability, Environmental Quality Management, Vol. 17, No. 2, 2007, pp. $81-88$

33. Qiu, S. (C.) et al., Can corporate social responsibility protect firm value during the COVID-19 pandemic?, International Journal of Hospitality Management, Vol. 93, 2021, pp. 1 - 12

34. Rivo-López, E. et al., Corporate Social Responsibility and Family Business in the Time of COVID-19: Changing Strategy?, Sustainability, Vol. 13, No. 4, 2021, pp. 1 - 13

35. Saiz-Álvarez, J. M. et al., B Corps: A Socioeconomic Approach for the COVID-19 Post-crisis, Frontiers in Psychology, Vol. 11, 2020, pp. 1 - 8

36. Santos Jaen, J. M. et al., Impact on companies of their socially responsible actions in the face of the pandemic generated by Covid-19, Razon Historica-Revista Hispanoamericana de Historia de Las Ideas, No. 46, 2020, pp. 1 - 11

37. Smith, D. K.; Casper, J., Making an Impact: An Initial Review of U.S. Sport League Corporate Social Responsibility Responses During COVID-19, International Journal of Sport Communication, Vol. 13, No. 3, 2020, pp. 335 - 343

38. Talbot, D.; Ordonez-Ponce, E., Canadian banks' responses to COVID-19: a strategic positioning analysis, Journal of Sustainable Finance \& Investment, Vol. 10, 2020, pp. 1 - 8

39. Terres, M. da S. et al., The COVID-19 Pandemic: paths for future research in marketing involving the regulatory role of prosocial consumption, Brazilian Journal of Marketing, Vol. 19, No. 3, 2020, pp. $611-641$

40. Valls Martínez, M. d. C.; Martin Cervantes, P. A., Testing the Resilience of CSR Stocks during the COVID-19 Crisis: A Transcontinental Analysis, Mathematics, Vol. 9, 2021, pp. 1 - 24

41. Vanapalli, K., R., et.al., Challenges and strategies for effective plastic waste management during and post COVID-19 pandemic, Science of The Total Environment, Vol. 750, 2021, pp. 1 - 10

42. Vázquez-Carrasco, R.; López-Pérez, M. E., Small \& medium-sized enterprises and Corporate Social Responsibility: a systematic review of the literature, Quality \& Quantity, Vol. 47, No. 6, 2013, pp. $3205-3218$

43. Vo-Thanh, T et al., How does hotel employees' satisfaction with the organization's COVID-19 responses affect job insecurity and job performance?, Journal of Sustainable Tourism, Vol. 29, No. 6, 2020, pp. 907 - 925 
44. Yang, K. et al., Effects of retailers' service quality and legitimacy on behavioral intention: the role of emotions during COVID-19, The Service Industries Journal, Vol. 41, No. 1-2, 2021, pp. $84-106$

45. Yelkikalan, N.; Köse, C., The effects of the financial crisis on corporate social responsibility, International Journal of Business and Social Science, Vol. 3, No. 3, 2012, pp. $292-300$

46. Winet, K; Winet, R. L., We're Here for You: The Unsolicited Covid-19 Email, Journal of Business and Technical Communication, Vol. 35, No. 1, 2021, pp. 134 - 139

47. Zengin Karaibrahimo, Y., Corporate social responsibility in times of financial crisis, African Journal of Business Management, Vol. 4, No. 4, 2010, pp. 382 - 389

48. Zhang, J.; Xie, C, The effect of corporate social responsibility on hotel employee safety behavior during COVID-19: The moderation of belief restoration and negative emotions, Journal of Hospitality and Tourism Management, Vol. 46, 2020, pp. 233 - 243

\section{WEBSITE REFERENCES}

1. European Commission, Commission StaffWorking document-Corporate Social Responsibility, Responsible Business Conduct, and Business and Human Rights: Overview of Progress, 2019, [ https://ec.europa.eu/docsroom/documents/34482?locale=hr], Accessed 10 March 2021 